\title{
Thoracoscopy: influence of the procedure on some respiratory and cardiac values
}

\author{
P FAURSCHOU, F MADSEN, K VISKUM \\ From Medical Department P, Bispebjerg Hospital, Copenhagen, Denmark
}

ABSTRACT In eight patients with pleural effusion arterial oxygen and carbon dioxide tensions $\left(\mathrm{PaO}_{2}\right.$ and $\left.\mathrm{PaCO}_{2}\right), \mathrm{pH}$, respiratory frequency, and cardiac rhythm and frequency were measured before, during, and after thoracoscopy. Four of the patients had a $\mathrm{PaO}_{2}$ below $70 \mathrm{~mm} \mathrm{Hg}(9 \cdot 3$ $\mathrm{kPa}$ ) before the procedure. During and after the procedure respiratory frequency increased and $\mathrm{PaCO}_{2}$ fell, indicating hyperventilation, while the other indices remained unchanged. It is concluded that respiration and the circulation readily adapt to the changes produced by the pneumothorax and the manipulation during thoracoscopy.

Thoracoscopy is an important technique in the diagnosis of pleural effusions. The procedure is simple and well tolerated and has few complications. ${ }^{2}$ During thoracoscopy, however, there is considerable collapse of the lung being investigated. Little has been reported on the complications of thoracoscopy, ${ }^{2}$ and only one study has dealt with respiratory and cardiac observations. ${ }^{3}$

Diagnostic procedures and anxiety are known to provoke tachycardia and cardiac dysrhythmias. ${ }^{3-5}$ In addition to the rearrangement of pulmonary flow and ventilation during thoracoscopy the patients might suffer from anxiety as well as pain, and cardiac dysrhythmia and tachycardia could therefore be expected during the procedure.

The aim of the present study was to determine the influence of thoracoscopy on respiratory frequency, arterial oxygen and carbon dioxide tensions $\left(\mathrm{PaO}_{2}\right.$ and $\left.\mathrm{PaCO}_{2}\right)$, arterial $\mathrm{pH}$, and the heart rhythm and rate.

\section{Patients and methods}

We studied eight patients admitted to the department because of pleural effusion. The age of the patients ranged from 21 to 76 years (mean 55 years); there were six men and two women. Before thoracoscopy 10-1500 ml (median $350 \mathrm{ml}$ ) of pleural fluid was evacuated by thoracocentesis.

The causes of the pleurisy were: pleural meta-

Address for reprint requests: Dr K Viskum, Medical Department P, Bispebjerg Hospital, Copenhagen NV, Denmark DK-2400.

Accepted 19 January 1983 stases, mesothelioma, rheumatoid pleurisy, pleuropneumonia, and tuberculous pleurisy (one case each); in three cases the aetiology remained unknown.

Seven patients had a normal electrocardiogram (ECG) (one of these had intermittent atrial fibrillation), and one had right bundle branch block. Two patients were receiving treatment with digoxin, one with verapamil, and two with diuretics. None of the patients had signs of cardiac failure at the time of thoracoscopy.

All the patients were smokers. In addition to the disease leading to thoracoscopy two had chronic bronchitis. Spirometry was not performed in any of the patients.

Four patients had a $\mathrm{PaO}_{2}$ below $70 \mathrm{~mm} \mathrm{Hg}(9.3$ $\mathrm{kPa}$ ) before the procedure; none had hypercapnia.

\section{Methods}

Thoracoscopy was performed under local anaesthesia with rigid thoracoscopes as previously described. ${ }^{1}$ Half an hour before the procedure 25 $\mathrm{mg}$ of levomepromazin was given intramuscularly. No oxygen was given during or after the procedure. Pleural drainage was not used. Arterial blood was drawn (1) in the resting state before the procedure; (2) after evacuation of pleural fluid and insufflation of air; (3) immediately after the trocar had been inserted and opened; (4) after the thoracoscopy had been started; (5) immediately after the incision had been closed after thoracoscopy; and (6) one hour after the procedure was finished. The blood was drawn from an indwelling catheter in the radial artery. Analysis for $\mathrm{pH}, \mathrm{PaO}_{2}$, and $\mathrm{PaCO}_{2}$ was per- 
Table 1 Median values of $\mathrm{pH}$, arterial carbon dioxide tension $\left(\mathrm{PaCO}_{2}\right)$, arterial oxygen tension $\left(\mathrm{PaO}_{2}\right)$, and respiratory and cardiac frequency before, during and after thoracoscopy

\begin{tabular}{|c|c|c|c|c|c|c|}
\hline & Before procedure & $\begin{array}{l}\text { After thoraco- } \\
\text { centesis and in- } \\
\text { sufflation of air }\end{array}$ & $\begin{array}{l}\text { After trocar was } \\
\text { opened }\end{array}$ & $\begin{array}{l}\text { During thoraco- } \\
\text { scopy }\end{array}$ & $\begin{array}{l}\text { After closure of } \\
\text { incision }\end{array}$ & $\begin{array}{l}1 \mathrm{~h} \text { after proce- } \\
\text { dure }\end{array}$ \\
\hline $\begin{array}{l}\mathrm{pH} \\
\mathrm{PaCO}_{2}(\mathrm{~mm} \mathrm{Hg}) \\
\mathrm{PaO}_{2}(\mathrm{~mm} \mathrm{Hg}) \\
\text { Respiratory }\end{array}$ & $\begin{array}{l}7 \cdot 43 \\
36 \cdot 6 \\
74 \cdot 8\end{array}$ & $\begin{array}{l}7.42 \\
33 \cdot 4 \\
71 \cdot 8\end{array}$ & $\begin{array}{l}7 \cdot 43 \\
33 \cdot 1 \\
75 \cdot 8\end{array}$ & $\begin{array}{l}7 \cdot 43 \\
33 \cdot 3 \\
66 \cdot 8\end{array}$ & $\begin{array}{l}7 \cdot 43 \\
33 \cdot 0 \\
71 \cdot 6\end{array}$ & $\begin{array}{l}7.44 \\
31.9 \\
70.0\end{array}$ \\
\hline $\begin{array}{l}\text { frequency/min } \\
\text { Heart rate/min } \\
\text { (range) }\end{array}$ & $\begin{array}{l}19 \\
78 \\
(60-102)\end{array}$ & 22 & $\begin{array}{l}84 \\
(72-108)\end{array}$ & $\begin{array}{l}28 \\
90 \\
(84-102)\end{array}$ & $\begin{array}{l}87 \\
(72-108)\end{array}$ & 24 \\
\hline
\end{tabular}

Conversion: Traditional to SI units-Blood gases: $1 \mathrm{~mm} \mathrm{Hg}=0.133 \mathrm{kPa}$.

Table 2 Arterial oxygen tension $\left(\mathrm{PaO}_{2}\right)$ and arterial carbon dioxide tension $\left(\mathrm{PaCO}_{2}\right)(\mathrm{mm} \mathrm{Hg})$ and respiratory frequency (f) during thoracoscopy in eight patients

\begin{tabular}{|c|c|c|c|c|c|c|c|c|c|c|c|c|c|c|c|c|c|}
\hline \multirow[t]{2}{*}{$\begin{array}{l}\text { Patient } \\
\text { No }\end{array}$} & \multirow[t]{2}{*}{ Age } & \multicolumn{3}{|c|}{ Before procedure } & \multicolumn{3}{|c|}{$\begin{array}{l}\text { After thoraco- } \\
\text { centesis and in- } \\
\text { sufflation of air }\end{array}$} & \multicolumn{2}{|c|}{$\begin{array}{l}\text { After trocar was } \\
\text { opened }\end{array}$} & \multicolumn{3}{|c|}{$\begin{array}{l}\text { During thoraco- } \\
\text { scopy }\end{array}$} & \multicolumn{2}{|c|}{$\begin{array}{l}\text { After closure of } \\
\text { incision }\end{array}$} & \multicolumn{3}{|c|}{$\begin{array}{l}1 \text { h after } \\
\text { procedure }\end{array}$} \\
\hline & & $\mathrm{PaO}_{2}$ & $\mathrm{PaCO}_{2}$ & $f$ & $\mathrm{PaO}_{2}$ & $\mathrm{PaCO}_{2}$ & $f$ & $\mathrm{PaO}_{2}$ & $\mathrm{PaCO}_{2}$ & $\mathrm{PaO}_{2}$ & $\mathrm{PaCO}_{2}$ & $f$ & $\mathrm{PaO}_{2}$ & $\mathrm{PaCO}_{2}$ & $\mathrm{PaO}_{2}$ & $\mathrm{PaCO}_{2}$ & $f$ \\
\hline $\begin{array}{l}1 \\
2 \\
3 \\
4 \\
5 \\
6 \\
7 \\
8\end{array}$ & $\begin{array}{l}55 \\
61 \\
45 \\
67 \\
76 \\
61 \\
56 \\
21\end{array}$ & $\begin{array}{r}42 \cdot 3 \\
60.0 \\
65.6 \\
69.6 \\
80.0 \\
82.4 \\
84.7 \\
100 \cdot 1\end{array}$ & $\begin{array}{l}36 \cdot 2 \\
33 \cdot 0 \\
36 \cdot 9 \\
38 \cdot 7 \\
34 \cdot 4 \\
38 \cdot 2 \\
35 \cdot 5 \\
36 \cdot 9\end{array}$ & $\begin{array}{l}30 \\
30 \\
16 \\
18 \\
16 \\
20 \\
16 \\
28\end{array}$ & $\begin{array}{l}43 \cdot 3 \\
78 \cdot 1 \\
62 \cdot 3 \\
72 \cdot 4 \\
79 \cdot 5 \\
71 \cdot 1 \\
67 \cdot 2 \\
82 \cdot 1\end{array}$ & $\begin{array}{l}22 \cdot 1 \\
27.0 \\
32 \cdot 5 \\
38.7 \\
37 \cdot 2 \\
30.0 \\
33.6 \\
34.2\end{array}$ & $\begin{array}{l}32 \\
28 \\
16 \\
24 \\
20 \\
20 \\
20 \\
24\end{array}$ & $\begin{array}{l}44 \cdot 4 \\
64 \cdot 9 \\
72 \cdot 5 \\
67 \cdot 2 \\
89 \cdot 8 \\
79 \cdot 0 \\
80.1 \\
85 \cdot 1\end{array}$ & $\begin{array}{l}29.7 \\
27.0 \\
30.7 \\
36.6 \\
34.8 \\
35.6 \\
31.7 \\
34.4\end{array}$ & $\begin{array}{l}40 \cdot 0 \\
65 \cdot 0 \\
68 \cdot 7 \\
61 \cdot 0 \\
89.3 \\
60.1 \\
78 \cdot 5 \\
81 \cdot 5\end{array}$ & $\begin{array}{l}32 \cdot 7 \\
25 \cdot 0 \\
31 \cdot 0 \\
34 \cdot 8 \\
33 \cdot 5 \\
35 \cdot 1 \\
33 \cdot 0 \\
34 \cdot 4\end{array}$ & $\begin{array}{l}32 \\
44 \\
20 \\
36 \\
20 \\
24 \\
28 \\
28\end{array}$ & $\begin{array}{l}39.7 \\
65 \cdot 0 \\
68 \cdot 9 \\
63 \cdot 5 \\
82.2 \\
79.7 \\
74.4 \\
73.3\end{array}$ & $\begin{array}{l}31.4 \\
28.0 \\
32.9 \\
33.3 \\
33.0 \\
38.3 \\
30.1 \\
35.8\end{array}$ & $\begin{array}{l}45 \cdot 2 \\
70 \cdot 1 \\
61 \cdot 3 \\
67 \cdot 7 \\
69 \cdot 9 \\
77 \cdot 3 \\
73 \cdot 5 \\
84 \cdot 1\end{array}$ & $\begin{array}{l}31.4 \\
29.0 \\
28.8 \\
33.7 \\
36.2 \\
33.0 \\
32.4 \\
30.5\end{array}$ & $\begin{array}{l}30 \\
30 \\
24 \\
24 \\
18 \\
18 \\
? 4 \\
24\end{array}$ \\
\hline
\end{tabular}

Conversion: Traditional to SI units-Blood gases: $1 \mathrm{~mm} \mathrm{Hg}=0.1333 \mathrm{kPa}$.

formed with an ABL-2 (Radiometer, Copenhagen). The respiratory frequency was counted (1) before the procedure; (2) after thoracocentesis with air insufflation; (3) during the thoracoscopy; and (4) one hour after the procedure. A single-lead ECG was recorded continuously from five minutes before the beginning of the procedure until five minutes after it was finished. The various stages of the procedure, including biopsies, were recorded on the ECG strip. The average duration was 15 minutes.

The Friedmann two-way analysis of variance in related samples has been used for statistical analysis.

\section{Results}

The median values of $\mathrm{PaO}_{2}, \mathrm{PaCO}_{2}, \mathrm{pH}$, and respiratory and cardiac frequencies are shown in table 1. Values for $\mathrm{PaO}_{2}$ and $\mathrm{PaCO}_{2}$ and respiratory frequency for the individual patients are shown in table 2.

$\mathrm{PaO}_{2}$ and $\mathrm{pH}$ showed no significant variation during the period of observation. The respiratory frequency increased significantly $(p<0.05)$ and the $\mathrm{PaCO}_{2}$ fell significantly $(\mathrm{p}<0.05)$, while the heart frequency increased insignificantly $(p<0.5)$.

The ECG strip showed that less than $2 \%$ of all beats were supraventricular premature beats at any stage of the procedure. No ventricular premature beats or other arrhythmias were seen.

\section{Discussion}

During thoracoscopy the lung on the side being investigated is collapsed to get as good a view as possible. Often patients with decreased lung function are investigated and little is known of the consequences of the sudden changes in ventilation and perfusion during the procedure. Oldenburg and Newhouse ${ }^{3}$ studied 12 patients with initially normal arterial oxygen saturation who underwent thoracoscopy and they found insignificant changes in the oxygen saturation and cardiac rhythm during the procedure. Our study included patients with abnormally low values of $\mathrm{PaO}_{2}$. A significant increase in respiratory frequency and a reduction in $\mathrm{PaCO}_{2}$ were seen. No significant changes in $\mathrm{PaO}_{2}, \mathrm{pH}$, cardiac rhythm or cardiac frequency were seen.

Even patients with low $\mathrm{PaO}_{2}$ were able to adapt ventilation and perfusion very quickly to the new conditions imposed by the thoracoscopy, and, to judge by the rate and rhythm, no undue strain was put on the heart by the new circulatory conditions. The psychological stress and the discomfort during the procedure, including the short pain inflicted by 
the biopsies done without local anaesthesia, provoked an insignificant number of premature beats and a very modest tachycardia compared with the changes produced by gastroscopy ${ }^{4}$ and, in house officers, grand rounds. ${ }^{5}$ The reason could be the effective premedication. ${ }^{4}$ The thoracoscopies and arterial cannulations were uncomplicated.

We conclude that thoracoscopy of 15 minutes' duration is well tolerated from the respiratory and circulatory point of view by patients with normal or decreased $\mathrm{PaO}_{2}$ and without heart failure.

\section{References}

${ }^{1}$ Enk B, Viskum K. Diagnostic thoracoscopy. Eur J Respir Dis 1981;62:344-51.

${ }^{2}$ Viskum K, Enk B. Complications of thoracoscopy. Poumon coeur 1981;37:25-8.

${ }^{3}$ Oldenburg FA, Newhouse MT. Thoracoscopy. Chest 1979;75:45-50.

${ }^{4}$ Levy N, Abinader E. Continuous electrocardiographic monitoring with Holter electrocardiocorder throughout all stages of gastroscopy. Dig Dis 1977;22:10916.

${ }^{5}$ Moss AJ, Wynar B. Tachycardia in house officers presenting cases at Grand Rounds. Ann Intern Med 1970;72:255-6. 